\title{
A Close and Practical Association with the Medical Profession: Scottish Medical Social Workers and Social Medicine, 1940-1975
}

\author{
CHRIS NOTTINGHAM and RONA DOUGALL*
}

This study is concerned with the development of the profession of almoner (renamed medical social worker in the 1960s) in Scotland in the period from the outbreak of the Second World War until the mid-1970s. In addition to primary and secondary documentary sources, it is based on extended interviews with practitioners of different generations, the collected personal records of individuals, and a witness seminar which involved medical social workers, members of parallel professions, and those who carried political responsibility for social work both at the Scottish Office and within the local authorities during the critical years. ${ }^{1}$

The story of the development of a small, well organized, purposeful, predominantly female, profession would be worth telling for its own sake, but there are wider implications. In the first place this is an example of a profession or, to be more specific, what we shall call an insecure profession, developing initially within one professional jurisdiction, the medical, and then switching to another, social work. As such, it offers an insight into the dynamics of professional politics. Secondly, there are social change issues and their impact on health services; all professions mirror the times in which they operate but the almoners' experience was particularly interesting because they engaged with issues of poverty, poor housing, abortion, adoption, and domestic violence in a period when popular and professional attitudes were subject to challenge and change. Thirdly, the story carries implications for the NHS as a whole. Currently the social contexts of health and medicine are much debated and often outlined as if they rested on novel insights. In reality, there have always been individuals and organizations arguing passionately for the social dimension. By 1948 politicians and prominent physicians had identified the almoners as a way of advancing social medicine. Over the next twenty years the profession did much to justify such expectations. Almoners, or medical social workers, were never as numerous on the wards and surgeries of the NHS as they would have liked but they became a part of many

(C) Chris Nottingham and Rona Dougall 2007

*Chris Nottingham, PhD, Centre for the Social History of Health and Healthcare, Glasgow Caledonian University, Cowcaddens Road, Glasgow, G4 0BA, UK; e-mail: c.nottingham@gcal.ac.uk.

Rona Dougall, PhD, Public Health Researcher, NHS Greater Glasgow \& Clyde.

We wish to express our thanks to the Wellcome Trust for the award which made possible the research and the witness seminar on which this paper is based, and to the individual medical social workers who have helped us with their ideas, their memories, their records, their encouragement, and their patience in explaining things which were obvious to them but a mystery to us. We are also grateful to those who participated in the witness seminar.

\footnotetext{
${ }^{1}$ The research involved eighteen extended interviews with past and present medical social workers. Tapes and transcripts of the interviews are located in Research Collections in the Library of Glasgow Caledonian University. Tapes and transcripts of the witness seminar are in the same location, as are
} 


\section{Chris Nottingham and Rona Dougall}

medical teams and were involved in the "social" education of other health professionals, including doctors. In the late 1960s changes began which would take the profession out of the NHS and into the new social work departments of the local authorities. At the same time, the profession lost its separate identity and became part of the new generic social work profession. The developments, which in Scotland were completed with the reorganization of local government in 1975, represented, in the view of many practitioners, the moment when their profession lost its effectiveness. In discussing why this happened, it is possible to shed light on some of the difficulties of embedding social considerations in the practice of health care. The significance of this debate becomes clear when we note the striking parallel between what have recently been identified as key service weaknesses and what the almoners were trying to promote: an informed social input into clinical decisions on wards and in surgeries, and continuity of care linking primary and secondary, health and welfare, and state and voluntary services. Not for the first time, the intricacies of professional politics appear to have thwarted desirable ends. That the activities of almoners promised not only better but also more cost effective care only adds a degree of mystery.

\section{Origins}

The role of almoner in Scotland, as elsewhere, had its origins in charitable work in hospitals. In the Glasgow Royal Infirmary, for example, the almoner function stemmed from the Dorcas Society, founded in 1863, through which "doctors' wives and other ladies of comfortable means" tried to make the lives of the sick poor more comfortable and spiritually meaningful. ${ }^{2}$ The work, though charitable, had a utilitarian edge: " $[\mathrm{B}] \mathrm{y}$ catering to the physical needs of discharged patients, [it] ensured that many who might otherwise have relapsed, and sought readmittance to the wards, were able to recuperate at home."3 In other Scottish hospitals a similar role was performed by samaritan societies. The modern profession is usually traced to the point where the Charity Organisation Society (COS) placed a trained social worker in the outpatients' department of the Royal Free Hospital in London in 1895 to ensure that only those needing free treatment obtained it. ${ }^{4}$ The initial opposition of the medical profession began to decline and other London hospitals followed. A Hospital Almoners' Association was formed in 1903. By 1914 the newly formed Institute of Almoners had assumed a broader role; linking hospitals and charities, and undertaking what they described as "missionary work" about their potential contribution with "hospital authorities, local Charity Organisation Society committees, women's

a collection of reminiscences of their working lives by a number of Scottish medical social workers. We are greatly indebted to Winnie Childs for the last, as it was she who persuaded many of her colleagues to record their memories and share them with us.

${ }^{2}$ Jacqueline Jenkinson, Michael Moss and Iain

Russell, The Royal: the history of the Glasgow Royal Infirmary, 1794-1994, Glasgow, the Bicentenary

Committee on behalf of the Glasgow Royal Infirmary

NHS Trust, 1994, p. 118.
${ }^{3}$ Ibid., p. 119. See also Dorcas Society Records, Greater Glasgow NHS Board Archive, $\mathrm{HB} / 14 / 12 / 5$.

${ }^{4}$ Almoners in the Mary Stewart mould were referred to as "lady almoners" to distinguish them from an older type of almoner, invariably male and exclusively concerned with money matters. We are indebted to Joan Baraclough for this information. "Lady almoner" was a term which many almoners disliked intensely. 


\section{Scottish Medical Social Workers and Social Medicine, 1940-1975}

colleges, training centres, [and] employment bureaux". 5 Though small, with only thirty trained almoners in twenty hospitals, the profession was recognized as suitable for educated middle-class women. Guests at one gathering included the principals of Somerville College Oxford, Bedford College London, and tutors from the London School of Economics. Close relations existed with the schools of social studies at the universities of Bristol, Birmingham, Edinburgh, Glasgow, Leeds, Liverpool, and Manchester. ${ }^{6}$ In the inter-war period a pattern of recruitment and training was established; a social studies degree followed by a year of lectures and placements with the Institute of Almoners in London, or a diploma in social studies with two years at the Institute. The training emphasized the distinctiveness of the role which students were expected to assume. They should cooperate with other professionals, indeed teamwork was something of a mantra, but they should never lose their sense of location in both the medical and social spheres. A particular feature of the Institute's course, much valued by many who experienced it, was the opportunity to learn about specific medical conditions, provided in part by doctors who lectured to the students. This pattern of education was to last until the later 1960s when the Institute stopped its courses and all remaining educational activities were transferred to university departments.

The years between the wars brought a wider recognition of the connections between social conditions and ill health. The Institute of Almoners urged local authorities to appoint almoners to their social service departments, but only a few complied. ${ }^{7}$ However, some doctors' attitudes were changing. By the time the Royal Infirmary in Glasgow appointed Miss Alison Keen as its first official almoner in 1934, she could benefit from "a growing awareness in the medical profession that social circumstances were often fundamental to the nature of a patient's illness". There were now six hospitals in Scotland employing nine trained almoners. ${ }^{8}$ Some complained that they were used for clerical tasks, and their "knowledge of social conditions and the prognosis of disease" ignored. ${ }^{9}$ Numbers, however, continued to rise, and the Institute confidently outlined a comprehensive service: investigating patients' home circumstances, planning convalescences, seeking funds for appliances and extra nourishment for poorer patients, arranging visits by district nurses or admissions to homes for discharged patients, and liaising with Public Assistance Committees and charities.

The war brought new opportunities, such as evacuation, for which a well-educated and resourceful body of women was invaluable. More significantly, it empowered those who had been arguing for a reassessment of health and welfare services. One historian of the profession concluded that the war emergency had highlighted the contribution almoners could make, and enabled the profession to escape routine work and

\footnotetext{
${ }^{5} \mathrm{M}$ W Edminson, 'The middle period, or episode two, 1914 to 1939', The Almoner, 1953, 6 (8): 360-72, p. 363.

${ }^{6}$ Ibid., p. 366. The first years of the twentieth century produced one significant breakthrough when the work of the St Thomas' almoners with maternity cases was recognized by the Local Government Board report on infant mortality. E Moberly Bell, The story of
}

hospital almoners: the birth of a profession, London, Faber and Faber, 1961, p. 102.

${ }^{7}$ Edminson, op. cit., note 5 above, p. 370.

${ }^{8}$ Records of the Glasgow Royal Infirmary (hereafter GRI), Almoners' Department, Greater Glasgow Health Board Archive, HB14.12/1-14.

${ }^{9}$ Edminson, op. cit., note 5 above, p. 365. 


\section{Chris Nottingham and Rona Dougall}

establish itself on a social work footing. The war was also good for recruitment. By 1940 the Institute had a hundred students in training and Scotland was said to be "forging ahead". ${ }^{10}$

One significant advance was the report by the Royal College of Physicians in 1943, Certain aspects of social and preventive medicine, which recommended that "all hospitals should employ properly trained almoners and psychiatric social workers, both in the care of patients and in teaching students". ${ }^{11}$ The use of almoners in the education of medical students was reinforced in the Goodenough Report of $1944 .^{12}$ These advances followed two years of negotiations between the Institute of Almoners and the Royal College of Physicians on "the need for social work as a part of medical treatment", and the importance of "the link between doctor and almoner". ${ }^{13}$ An influential supporter of the almoners' cause in Scotland was Francis Crew, who occupied the chair of public health and social medicine at the University of Edinburgh from 1944 to $1955 .{ }^{14}$

One almoner worried that an infatuation with social medicine would lead them to neglect traditional welfare functions. ${ }^{15}$ The vast majority, however, embraced Crew's prospectus as traditional functions such as liaison with charities and searching for funds for special treatments seemed destined to decline with the coming of a more comprehensive welfare state. Besides, there was much to encourage ambition. The Minister of Health, Aneurin Bevan, was an enthusiastic supporter. "It is not possible", he stated, "to treat the patient irrespective of the social context in which the patient lives." The almoner had "become a very important part indeed of modern healing work" and was "an important link between the different sections of the Health Service". With the coming of the NHS, "a barrier will be lifted between the almoner and the patient and it will be possible for the almoner to approach the patient quite independently of financial considerations". ${ }^{16}$ A Ministry of Health circular of September 1948 provided "the first official recognition of the almoner's functions", ${ }^{17}$ defining her as "a medical social worker in the medical team". ${ }^{18}$ It confirmed the ambitious view of functions: "Social investigation and interviews to provide understanding of the social and personal background of the patient, and in particular to give the doctor information which is relevant to diagnosis and treatment" and to undertake "social action to minimize personal anxieties, family difficulties and other problems during illness". The almoners' department should be the "focal point" for teaching social

\footnotetext{
${ }^{10}$ M J Roxburgh, 'Episode three, 1939-1953', The Almoner, 1953, 6 (8): 373-81, p. 376.

${ }^{11}$ Joan Baraclough, Grace Dedman, Hazel Osborn, Phyllis Willmott, One hundred years of health-related social work, 1895-1995: then ... now ... onwards, Birmingham, British Association of Social Workers, 1996, p. 22.

${ }^{12}$ Report of the Inter-departmental Committee on Medical Schools, London, HMSO, 1944 (Goodenough Report). For the Institute of Almoners' own discussions of the evidence they wished to present to this committee, see British Association of Social Workers Collection: papers of the predecessor organizations 1890-1970 [MSS.378] Modern Records Centre, University of Warwick, MSS.378 A15/2:31.
}

\footnotetext{
${ }^{13}$ Ibid., Minutes of meeting 26 March 1942, MSS.378 A15/2:31.

${ }^{14}$ Rosemary I Weir, A leap in the dark: the origins and development of the Department of Nursing Studies, The University of Edinburgh, Penzance, published for the Department of Nursing Studies, University of Edinburgh, by the Pattern Press and the Jamieson Library, 1996, pp. 4-8.

${ }^{15}$ Elizabeth Stirling, 'Almoners and the relation to social medicine', The Almoner, 1948, 1 (4): 75-6.

${ }^{16}$ Aneurin Bevan in a speech to the AGM of the Institute of Almoners, March 1948, quoted in Baraclough et al., op. cit., note 11 above, p. 23.

${ }^{17}$ Roxburgh, op. cit., note 10 above, p. 378.

${ }^{18}$ Hospital Almoners, 1946 H.M.C. (48) 53; B.G. 48 (57) Sept. 1948.
} 
issues to student doctors and nurses. In professional terms this was critical as it recognized a discrete body of knowledge and expertise. Almoners' work should also be extended into the community. Additionally, they should be "confined to tasks for which they have special qualifications and ... they should have such clerical or administrative assistance as may be necessary", and "workers without training and qualifications, who are described as almoners but are doing administrative or clerical work should no longer be referred to as almoners". This important reinforcement of professional status was welcomed by the Institute. The internal committee it set up to ensure improvements were implemented directed that 'almoners' departments should be carefully scrutinized to eliminate any duties that could as well be carried on elsewhere in the hospital". ${ }^{19}$

In 1949 the Ministry of Health and the Department of Health for Scotland, appointed eight committees under the chairmanship of Sir Zachary Cope, the Committees on Medical Auxiliaries (the Cope Committee), to look at questions of supply, demand, training, qualification and professional regulation of all professions within the Health Service other than doctors and nurses. ${ }^{20}$ An immediate issue was low recruitment. As the key to the stable growth of any profession is its capacity not only to carve out an area of work which it is uniquely capable of undertaking but to deliver a constant service, the shortage was troublesome. The pool from which future almoners could be drawn was small. Entrants in Scotland would have to emerge from those possessing the Senior Leaving Certificate, the certificate of academic competence at the age of seventeen. In 1949, only 4,110 individuals attained this basic qualification and "from this pool must come nearly all entrants to the professions and a wide range of executive, secretarial and technical staff in the public services and in business". ${ }^{21}$ Cope recommended salaries for almoners "similar to those in occupations with comparable standards of training".

Cope was essentially supportive; the almoner, "a social case worker in the medical field", was "one of the essential elements of a complete hospital service, and indeed, of a complete health service". ${ }^{22}$ He suggested a ratio of one almoner per fifty beds in teaching and general hospitals, lamented that of forty-nine Scottish Hospital Groups only twelve were employing almoners, and reinforced the almoners' view that they should be relieved of all duties "which do not call for an almoner's training". 23

There was, however, a potentially destructive recommendation. Cope argued that almoners, along with other "auxiliary" professions, should, in terms of recruitment, registration and regulation, be collectively dealt with by one new body, similar to the General Medical Council, with representatives from these professions, but under a controlling majority of doctors. "It is inappropriate that professional associations should have undivided and final responsibility for such recognition for purposes of the National Health Service." 24

\footnotetext{
${ }^{19}$ Ibid. The membership of the internal committee included Eileen Younghusband of the London School of Economics, the Hon. Eleanor Plummer, Principal of the St Anne's Society, Oxford, and Dr J G Scadding, Dean of the Medical School of the Brompton Hospital. They also recommended an additional year of training in a university and, a long-standing
}

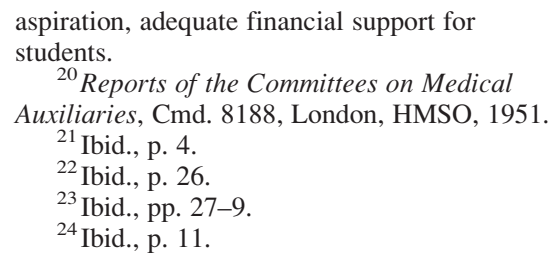




\section{Chris Nottingham and Rona Dougall}

This prompted the almoners' representatives, Miss Margaret J Roxburgh and Miss Marjorie McInnes, to issue a minority report:

The basis of our inability to agree with the proposals is that we are here dealing with professions. A profession is a calling having its own standards of training, principles of practice and its own professional ethic. Having been trained to professional competence[,] its members on qualification assume personal responsibility as guardians of the quality and integrity of work in the profession which they practise. ${ }^{25}$

The term "medical auxiliary" was offensive as it had "by common use come to denote an untrained or partially trained person, e.g., 'nursing auxiliary' ". They also objected to the assumption "that doctors can, by virtue of their medical training and experience, satisfactorily plan and control the curricula of training and methods of work of the professions under review". This was not a bid for independence, "We agree that members of our professions must work closely with the other specialists in the team treating the patient, of which team the Doctor is the undisputed leader." They sought "a very different basis of association" to that proposed by Cope but still one which provided "a means of establishing a close and practical association with the medical profession". ${ }^{26}$

The almoners prevailed. On 23 February 1954 the Conservative Minister of Health, Iain MacLeod, announced their exclusion: "I think that is right, because most people would agree that an almoner is not a medical auxiliary, but a social worker in the medical sphere." 27 Thus, with the support of politicians and sympathetic doctors, almoners shed irksome, routine work, acquired a set of complex functions within their exclusive competence, and established the Institute as their regulatory body. However, this was only first base. Health politics is littered with notions that begin with high level support but disappear somewhere down the line to implementation.

\section{Developing Practice}

The attitudes of the Royal Colleges and ministers did not automatically transfer to ward or surgery level. An almoner's ability to contribute constructively rested on the good will of professionals in her immediate vicinity. Social considerations had to find a place among other imperatives in the minds of working doctors. Similar considerations, of course, apply to most inter-professional relationships. Co-operation, for example, between doctors and nurses can be difficult but there is a mutual dependency that usually ensures a minimal working relationship. Almoners were useful but their contribution was not indispensable. One interviewee expressed this dilemma:

It's so sort of non-specific and not an essential part—you know everybody must have tests done and blood taken, you've got to have all the people to do all these sort of things and if people were really mentally ill, you've got a psychiatrist who will do that. You were sort of "In-Betweeners" who could perhaps be helpful, but it was very difficult to say precisely in what way we were helpful. ${ }^{28}$

\footnotetext{
${ }^{25}$ Ibid., p. 125.

${ }^{26}$ Ibid., pp. 125-6.

${ }^{27}$ Hansard, House of Commons, Tuesday, 23 Feb. 1954.
}

\footnotetext{
${ }^{28}$ Testimony from interview GCU/CCH T013 Almoners, Glasgow Caledonian University Archives (hereafter GCU Archives).
} 
One important index of success was the rate at which doctors referred patients to them. Poor relationships were manifested "by not referring people, or not being co-operative, that sort of thing". ${ }^{29}$ In the early days and in the worst working environments, almoners had to interview all patients to identify those who might benefit from their services. A better situation was where the doctor understood the almoner's function, was confident that she understood the rules of good professional practice, and referred where appropriate. $^{30}$

Our interviews offer insight into how almoners sought to turn abstract support into effective working relationships. In Dundee, for instance, almoners met resistance. The Royal Infirmary had had a basic service of the traditional kind. An untrained almoner, paid by the Samaritan Society, disbursed small grants to the needy and ran a clothing cupboard. In 1947, however, she was told there was no longer a room for her and the service folded. The root of the problem was a medical superintendent whose opposition to almoners was so intransigent that at one point the Institute blacklisted the hospital. When a young almoner was sent in that same year to work in orthopaedics with the outpatients at Maryfield, the former municipal hospital, she was used "informally" by two consultants at the Infirmary, but it was largely a matter of starting from scratch:

When I came to Dundee there were specialist voluntary organisations for the blind, the deaf, exservicemen, WRVS, Red Cross, Crippled Children, Grey Lodge Settlement, and the newly formed Old People's Welfare Committee, and statutorily there was the Local Authority Children's Department, but nothing in the way of a family orientated social work service.

Her first step was to establish a council of social service. Although isolated she drew support from fellow almoners:

At the beginning when I was on my own in Dundee and had no professional social work colleagues even in the community, I used to rush down to Perth every month and we all met for tea in a hotel at the station. I am sure that that helped keep me going and later on we became officially an Almoners' Group in the Scottish region of the Institute. ${ }^{31}$

In 1951 a Head Almoner was appointed at the Maryfield with the support of the superintendent, Dr W A Davidson, but the greatest breakthrough came with the appointment of Dr (later Professor) Alec Mair in 1952 as lecturer in public health at the Infirmary. He took the title "honorary consultant to the almoner service in the Eastern Regional Hospital Board Area" and immediately involved almoners in teaching and the development of resettlement clinics. Mair was actually responsible for bringing one almoner into the profession. At the time she was a social science graduate whose career as a personnel officer had been interrupted by illness. Mair, a friend of her family, saw her potential as an "inquiring hand of social medicine" and set her to combing hospital records to investigate how many of their elderly deaf patients had worked in the jute industry. Mair then introduced her on the geriatric unit of the Maryfield: "So that was the first time I had ever met an almoner, first time I'd ever heard of an

\footnotetext{
${ }^{29}$ Ibid.

${ }^{30}$ For an illustration of the importance that was placed on this question, see The Institute of Almoners, 'Report of the
}

Survey Committee', The Almoner, 1953, 6 (2): 61-9.

${ }^{31}$ Testimony from interview GCU/CCH T008 Almoners, GCU Archives. 


\section{Chris Nottingham and Rona Dougall}

almoner." 32 She prospered under Dr Taylor Brown, the consultant physician: "[T]he doctor would take me on the home visit, you know before the people actually came into hospital to see what the home circumstances were and what they would be going back to if they were going to be discharged." In 1955 she went to Edinburgh University to do the new medical social work course:

I can't remember now whether there were 8 or 10 of us-it was a very small course. I think they were still finding their way too- and they were enrolling medical staff from the medical school to help and they were $[$ sic $]$ - as I say this was just the second year of them having placements in the hospital. ${ }^{33}$

Her first placement was "in the maternity unit-the Simpson Hospital in Edinburghwhich was, I thought, absolutely awful. We saw all unmarried mothers yes, but we didn't see many others because I don't think anybody spent enough time with them to find out what their home circumstances were, you know". Her second placement, in the cardiac unit at the Western General in Edinburgh, was more encouraging:

The two consultants there, wanted to know what kind of people they were, how they coped with things, how they would deal with chest surgery, what sort of pressures they were under, what support they were getting, what they were going back to-and we were really encouraged to make, you know, complete social assessments of them, it was most helpful to us and our supervisor, that we felt these things were being read by the consultants.

Her final placement took her to the Edinburgh Medical School and the General Practice Teaching Unit. This was, she recalled,

a special unit in Edinburgh where some of the medical students came, but they were attached to the university so they too had very high standards of the care that they gave their patients and their knowledge of the whole family and the family situation and where they felt there were other things needed, you know, we took social histories and we tried to liaise with the local authority social department, things like that. It was very-there again you were working very closely with the doctors-an excellent group, I couldn't fault them. ${ }^{34}$

She was fortunate, for this unit represented the most advanced development in social medicine in Scotland. It brought her into contact with Jane Paterson, an almoner who had been appointed assistant lecturer in the Department of Public Health and Social Medicine of the Medical School led by Francis Crew. As Paterson recalled, her work involved both research and the teaching of medical students through day-to-day contact with patients "with a man called Richard Scott who was a senior lecturer in the Department of Social Medicine; between us we created a Department of General Practice". 35 They first

\footnotetext{
${ }^{32}$ Testimony from interview GCU/CCH T013 Almoners, GCU Archives.

${ }^{33}$ Ibid.

${ }^{34}$ Ibid.

${ }^{35}$ Testimony from interview GCU/CCH T016

Almoners, GCU Archives. Scott was a fervent and articulate supporter of the involvement of almoners in medical training: "It is no longer any guarantee, because a doctor has lived and worked over a number of years in a particular district of a town, because he is
}

essentially a humanist and a lover of mankind, because he is a trained and experienced observer, that he is therefore possessed of all the necessary knowledge of the physical and social circumstances of his patients." Richard Scott, 'The almoner and the family doctor', The Almoner, 1949, 1 (10): 209-14, p. 211. For Scott, the almoner was an essential element in both the training and the day-to-day practice of the GP: "the almoner is the solution to many of the problems of general practice." Leslie Briggs, 'Research almoners' 
worked in what had been the Royal Public Dispensary but in 1952 a Rockefeller grant enabled them to expand in the former dispensary in the Cowgate district. They first concentrated on specialist GP training, but in 1956 the University decided that all medical students would benefit from some contact with the unit. ${ }^{36}$

For an almoner in training such a unit represented a confirmation of the highest professional aspirations. After her training, the interviewee was reunited with Dr Taylor Brown who had moved to the big geriatric department of Woodend Hospital in Aberdeen. They resumed joint home visits and their easy collaboration. While he was examining the patient she would "have a chat with [the] daughter or neighbour or whoever it was and find their view of how much was needed". She and the doctor would discuss the case "in the car on the way back". 37

Aberdeen provided another illustration of the importance of medical support, albeit in a negative way. Here the Medical Officer of Health, Dr Ian McQueen, was keen on the social dimension but had his own notion of how this might best be promoted. As one interviewee, then working in the Royal Aberdeen Hospital for Sick Children, put it: "The Medical Officer of Health for Aberdeen City was making a tremendous drive for the importance of the role of health visiting to be recognised in many aspects bordering, if not positively invading, social work, which caused some tension." She felt that the effects were less serious for the almoners than might have been anticipated: "But our relationships at a personal level survived this surprisingly well because some of the health visitors were uncomfortable about the tremendous claims being made for them by Dr McQueen." 38

Another interviewee raised the Aberdeen case:

Dr McQueen was medical officer of health, his wife was a health visitor, or she had been, he was very anti medical social workers, really rabid about it - that because it should be, what he called, health visitors' answer to the problem, not these social workers-and he used to write to the press and all, and I used to write and reply! I also took it up with the MP as well-he was taking it to the House of Commons to do away with medical social workers-and health visitors should take over. ${ }^{39}$

Professional co-operation was difficult: “[H]ealth visitors were really something we didn't contemplate in Aberdeen because of this animosity." This did not apply elsewhere: "I don't know that I came across it as much in Edinburgh and Glasgow-in fact we hardly ever came across, for some reason or another, health visitors there-they seem to

group', The Almoner, 1950, 3 (4): 135-7, p. 136. Not everyone in social medicine was enthusiastic about involving almoners in medical education. Thomas McKeown, professor of social medicine at the University of Birmingham, felt that they could never match the high standards of teaching to which medical students were accustomed. Thomas McKeown, 'The contribution of the almoner in the teaching centre', The Almoner, 1948, 1 (2): 24-5.

${ }^{36}$ For a full account of this unit and Paterson's explanation of the specific contribution the almoner could make, see Jane Paterson, 'The almoner's contribution to medical teaching', The Almoner, 1950, 3 (5): 163-77. For Paterson, "the medical student has usually no difficulty whatsoever in obtaining information from the patient on social matters. His real difficulty lies in the interpretation of the facts" (pp. 164-5). What the almoners could contribute was a knowledge of "systems" which would enable the doctors to make sense of the facts.

${ }^{37}$ Testimony from interview GCU/CCH T013 Almoners, GCU Archives.

${ }^{38}$ Testimony from interview GCU/CCH T017 Almoners, GCU Archives.

${ }^{39}$ Testimony from interview GCU/CCH T014 Almoners, GCU Archives. McQueen's wife was not, as the interviewee believed, a health visitor although she was closely involved with both the profession and her 


\section{Chris Nottingham and Rona Dougall}

deal with babies and things like that, they regarded that as their job." ${ }^{40}$ However, another interviewee recalled, "We did a lot of work with health visitors." In Law Hospital, with long-term orthopaedic cases:

They were our link, they were very much our link, we didn't look on them as poaching on our preserves or, or vice versa, because they were the link with Glasgow, "For God's sake, Mr Gillespie's done a runner," you know, "Oh I'll see, I'll go out and do a visit and give you a ring and see what's what," you know what I mean? ${ }^{41}$

Although she did add: “Once I'd got to Robroyston, and then also the Queen Mother's especially, I think the health visitors were kind of moving into the social work scene at this point, I think this is what maybe created a bit of tension, you know." 42

Health visiting clearly overlapped the almoners' territory. In 1951 the Department of Health for Scotland sought the Institute of Almoners' views over proposed changes in health visitor education, and the Institute set up an ad hoc committee. This debate arose from an extension of the duties of health visitors in Section 24 of the Health Act, requiring Local Authorities to make provision "for the visiting of persons in their own home by ... health visitors for the purpose of giving advice as to the care of young children, persons suffering from illness, and expectant mothers and nursing mothers, and as to the methods necessary to prevent the spread of infection". ${ }^{43}$ A medical representative on the committee suggested that if health visitors were given a two-year social science training this "would do away with the need for almoners as a separate profession since the HV would be the medical social worker and would operate both in the hospital and in the community". He acknowledged problems "on an emotional or psychological level" would be beyond their competence but thought these could be dealt with by psychiatric social workers. Almoners would be left with patients' financial problems.

The almoners' representatives concluded that "caseworkers had apparently completely failed to define or explain what casework really is and wherein it differs from general social service". At the next meeting, Miss Mitchell of the Family Welfare Association set about rectifying the deficiency. ${ }^{44}$ "In her experience ... health visitors, if good, referred her clients to FWA for social casework. If not so good she tended to refer them only for material help, e.g. layettes and prams." Health visitors did "see themselves as all sufficient but they do not see the family and its problems as a whole". Moreover, health visitors knew little of social services and could not help with budgeting problems. She felt casework training could not be grafted onto a nursing training as it meant "rejecting the basic attitude acquired by the nurse". It also emerged that health visitors could have caseloads of 500 or more and this was clearly incompatible with the service that almoners provided. ${ }^{45}$

husband's aspirations. We are indebted to Lesley Diack, who has written extensively on health visiting in Aberdeen, for this information. For a discussion of the relationship in Scotland, see M Jeffreys, 'The social worker and the health visitor', Health Bulletin, 1973, 31 (2): 72-5

${ }^{40}$ Testimony from interview GCU/CCH T014 Almoners, GCU Archives.

${ }^{41}$ Testimony from interview GCU/CCH T008 Almoners, GCU Archives.

\footnotetext{
${ }^{42}$ Testimony from interview GCU/CCH T008 Almoners, GCU Archives.

${ }^{43}$ Institute of Almoners/Institute of Medical Social Workers papers from the British Association of Social Workers collection of the papers of the predecessor organizations 1890-1970, Modern Records Centre, University of Warwick, MSS.378 A15/16:4-9a, the committee operated from 17 Dec. 1951 to 8 May 1952.

${ }^{44}$ Ibid., 28 Feb. 1952, MSS.378 A15/16:8.

${ }^{45}$ Ibid., 28 Feb. 1952, MSS.378 A15/16:8.
} 


\section{Scottish Medical Social Workers and Social Medicine, 1940-1975}

One almoner recalled that matrons could also be a source of difficulty:

Matrons reigned supreme over the life, work and morals of their subordinates. That another woman should be brought in, not owing allegiance to the matron, was indeed a grievance which could easily rankle. Fortunately there were notable exceptions but often a state of "watchful neutrality" was the best that could be achieved. ${ }^{46}$

Most interviewees, though, claimed to have enjoyed good working relationships with nursing staff. One recalled, "I had no difficulty. I mean, I just found them all very friendly and pleasant." ${ }^{47}$ Another felt nurses "were not a race apart - they wanted to know about other things in the lives of their patients" ${ }^{48}$ Yet another, remembering her work in the Glasgow Royal Infirmary in the 1940s, felt sisters could provide critical assistance:

One who stands out in my memory who was very efficient, very good, she made all the difference, because she in a way would, perhaps find more social problems just talking to the patients and she was in the ward longer than, say the chief, who would just walk around, you know and just deal with the medical, physical side of things. And she was very helpful-I remember her being outstanding really-I mean she could admit 20 patients in an afternoon and she would know all about their circumstances and who was at home and you know to look after them when they went back—by the next morning—very efficient. ${ }^{49}$

A similar view was put forward by an interviewee who recalled an experience in a London hospital in the 1960s:

One of the surgeons hated his patients to die of terminal cancer. Now he wouldn't have said that, he would have just said that, you know, they would get better care at the kind of, the hospice. The NHS hospice was a dreary place, and it was a long way from the suburb of London where we worked. It was cruel to send people there, because their relatives, you know, couldn't just pop in and out. And the ward sister and I just kind of, without officially talking about it, played this little kind of game of, you know, the referral had been made, and I would just take that extra long time to go and discuss it with sister, and I'd get the forms completed, and she would delay getting the forms completed, and whatever. Because the ward sisters are always the ones who knew when the patient was going to die, because they were so experienced, they could see, you know, the signs. So, we usually kind of won. (laughs) ${ }^{50}$

In general almoners were confident of their position with respect to nurses. They felt they possessed a distinct body of knowledge and were, in most cases, able to communicate more effectively with patients as a result of their specialized casework training and experience.

Complicity with all professionals was desirable, but doctors were the key. From almoners' accounts, however, doctors do not emerge as a monolithic bloc. Almoners developed an acute sense of individual dispositions and they shared information. One recalled a young doctor who was "tremendously aware of patients' social and personal circumstances". When she met the head almoner at the Westminster Hospital where he had trained and complimented her on her good work, she was told, " 'Oh no, he was born like that'." ${ }^{51}$ A male

\footnotetext{
${ }^{46}$ L C Marx, 'Early days', The Almoner, 1953, 6 (8): $346-59$, p. 356.

${ }^{47}$ Testimony from interview GCU/CCH T009 Almoners, GCU Archives.

${ }^{48}$ Testimony from interview GCU/CCH T013 Almoners, GCU Archives.
}

\footnotetext{
${ }^{49}$ Testimony from interview GCU/CCH T011 Almoners, GCU Archives.

${ }^{50}$ Testimony from interview GCU/CCH T008 Almoners, GCU Archives.

${ }^{51}$ Testimony from interview GCU/CCH T008 Almoners, GCU Archives.
} 


\section{Chris Nottingham and Rona Dougall}

interviewee thought even sceptical doctors could be brought round, "provided you did good work and you were able to prove that it was successful". His technique was "to write up reports maybe six-monthly and follow up people and write these up, so then they could see what happened to these people and how we helped them, you know, to break through that barrier". When offered the opportunity to lecture fifth year medical students he was "a bit apprehensive", but based his teaching on patient case histories: "[M]aybe I'd find out which wards they were working on-you know, and which cases they were actually dealing with so then I was able to link that up and stimulate their interest, they could see that. So it went down quite a treat." 52

Jane Paterson was more confident with medical students in Edinburgh: "I saw them individually, and taught them on their case-you know, what they should be doing, what should they be thinking about, what should they be planning for this patient." Asked about the students' attitude to her as an almoner she replied:

Their attitude? Well, I think they found it hard to believe that this was any of their responsibility to begin with and then once they'd had a discussion with me they began to see that you couldn't just treat people like that, you had to know what they were up to and what their needs were, social as well as medical. ${ }^{53}$

Paterson's approach reflected her position as a lecturer in the Medical School and support from above, as well as a justifiable confidence in her capabilities. However, while the period from 1948 to the end of the 1960s was one of advance, the case for the social dimension demanded constant promotion.

The profession's progress during these years can be traced through the Glasgow Royal Infirmary, one of its most successful areas of operation. As mentioned above, the department was set up in 1934 under Alison Keen. Marjorie McInnes recalled that in the years immediately before the NHS, "[W]e were absolutely exhausted ... with raising money for appliances." "A lot of improvisation" was demanded in supplying clothes for patients going to convalescent homes, covering the rents of poorer patients to prevent eviction, and paying for funerals. This required "access to all sorts of charities". At the Gentlewomen's Society "you could negotiate a life pension there for someone who was a genuine person, I mean with no family support for instance". The work also demanded home visiting. Even McInnes, a formidable advocate of the advanced definition of the profession's role, found it difficult to remember her purpose "wasn't just a question of meeting basic need, it was boosting the personality at the same time". 54

By 1948 the department had ten qualified staff. The almoners warned that anyone anticipating immediate improvement with the introduction of the welfare state was likely to be disappointed: "Problems of bad housing and unsuitable working conditions tend to predominate." ${ }^{55}$ By 1952 the department reported that, in addition to nurses and medical students, they were lecturing to physiotherapy and audiometrics students. ${ }^{56}$ By 1957

\footnotetext{
${ }^{52}$ Testimony from interview GCU/CCH T014 Almoners, GCU Archives.

${ }^{53}$ Testimony from interview GCU/CCH T016 Almoners, GCU Archives.

${ }^{54}$ Testimony from interview GCU/CCH T006 Almoners, GCU Archives.
}

\footnotetext{
${ }^{55}$ GRI, Almoners' Department, Report to Board of Managers, 1948, Greater Glasgow Health Board Archive, HB 14.12/1-14.

${ }^{56}$ GRI, Almoners' Department, Report to Board of Managers, 1952, Greater Glasgow Health Board Archive, HB 14.12/1-14.
} 


\section{Scottish Medical Social Workers and Social Medicine, 1940-1975}

referrals from medical staff were working so well that the policy of routine interviewing of all patients was no longer necessary. ${ }^{57}$ Some of the success in the Royal must be attributed to exceptional leadership. From our interviews it is clear that Alison Keen inspired successive generations of almoners. One who trained under her in the earlier period spoke of her as "an awfully nice person, very sort of calm, and she would give people the idea that she had the whole day to spend and then she would be there half the night herself, just - she was very kind to the staff", ${ }^{58}$ For another, who worked at the Royal in the 1960s, "[S]he was a fantastic person to have as head of department, she was very well respected in the hospital, very well known, and her department was seen as a very credible and integral part of that hospital scene." ${ }^{, 59}$ Another factor in the Department's success may have been the capacity of the east end of Glasgow to produce patients with obvious social needs.

The range of problems dealt with at the Royal, as elsewhere in Glasgow, was vast. One almoner active in the 1950s recalled, "A lot of them were marital problems, drunken husbands who knocked them about. Financial problems. Oh! I used to have my desk covered with payment books for clubs." 60 Jane Paterson in Edinburgh was also dealing with "an awful lot of marital problems, people not getting on with their husbands and so forth, but eh, there were all sorts of things, you could hardly list the sort of problems that there were" ${ }^{61}$ One almoner, working at the Western Infirmary in Glasgow, was anxious to specialize in alcoholism and rehabilitation, but often spent time writing to charities. ${ }^{62}$ Another spoke of the importance of co-operation with the Disablement Rehabilitation Officer at the Ministry of Labour and her network of contacts with employers. ${ }^{63}$ Other duties included securing places in convalescent and local authority homes but this still often involved approaching charities for suitable clothing. The wards at the Belvedere Hospital in Glasgow, originally a fever hospital, were a constant source of patients with profound social needs. "The TB wards could have done with an almoner each ... particularly female TB wards. You know women would be in for months, you know, their children being away some place, they'd all be worried about their children, they'd be up and away." ${ }^{64}$ Other conditions made specific demands: "Things like multiple sclerosis, you know, where it was a deteriorating illness. And of course with cancers. Of course in those days away back, they didn't ever tell anybody what was wrong, the word was never mentioned." ${ }^{65}$ In some places psychological medicine produced a volume of referrals. Doctors in the Department of Psychological Medicine at the Edinburgh Royal regularly referred women with depression to the almoner. ${ }^{66}$ Child patients provided another area

\footnotetext{
${ }^{57}$ GRI, Almoners' Department, Report to Board of Managers, 1957, Greater

Glasgow Health Board Archive, HB 14.12/1-14.

${ }^{58}$ Testimony from interview GCU/CCH T011 Almoners, GCU Archives.

${ }^{59}$ Testimony from interview GCU/CCH T015 Almoners, GCU Archives.

${ }^{60}$ Testimony from interview GCU/CCH T009 Almoners, GCU Archives.

${ }^{61}$ Testimony from interview GCU/CCH T016 Almoners, GCU Archives.
}

\footnotetext{
${ }^{62}$ Testimony from interview GCU/CCH T014 Almoners, GCU Archives.

${ }^{63}$ Testimony from interview GCU/CCH T009 Almoners, GCU Archives.

${ }^{64}$ Ibid.

${ }^{65}$ From the interviews it emerged that many almoners disagreed with keeping patients and families ignorant of terminal diagnoses and that they were one of the influences that produced change.

${ }^{66}$ GD2/5/4 Lothian HB archive, Edinburgh University Library.
} 


\section{Chris Nottingham and Rona Dougall}

where the expertise of the almoner was routinely sought, and here almoners made a distinctive contribution, exercising pressure to allow parents more access. ${ }^{67}$

Clearly the contribution of almoners was more valuable, and valued, in some areas of medicine than others. Almoners, ever conscious of their small numbers in the face of the volume of need, learnt to select areas where they could have greatest effect. One method was to identify the most willing recipients of their input. Physicians were more likely to be "concerned about patients' backgrounds and whatnot than surgeons". ${ }^{68}$ An interviewee recalled that even in the Glasgow Royal the surgeons made little use of almoners:

They get somebody in, something has to be done; they cut it out or do what they have to do, that's it, fixed, fine, get the patient out. But, with physicians, so many conditions are so, well, are psychosomatic, so many are so much involved with the person, that you can't just say, that's the illness, that's the person, that they always were much more interested ... I hardly ever worked in a surgical ward come to think of it, at the Royal. No. For a very short time I was, yes, mm, [inaudible] surgical. And at their ward meetings, which were then just starting, it was more or less a matter of, you know, when could you get this man out. ${ }^{69}$

In other areas of specialization, however, it was different:

One really did do a hard day's work at Law [Hospital], I mean, and the surgeons knew why you were there, the orthopaedic men, not the surgeons, they were away in a world of their own, but the orthopaedics and the TB, and the medical units, really, you felt really a part of, you know? You really ... you were right in there, you know? ${ }^{70}$

Another interviewee "was greatly impressed with the geriatric physicians". They grasped "the importance of seeing their patient immediately as a person with a background and a history". ${ }^{71}$

\section{Responses to Change}

The continuing development of the profession required almoners' leaders to cultivate the most willing recipients of their expertise at the representative level just as their members were doing at hospital level. In 1956 the Institute invited the Royal College of Physicians, their traditional supporters, to discuss the "many changes which have had far-reaching effects on both medical and social services in this country". The Institute noted that since the Report of 1942 there had been a "growing emphasis in medical education on the need to understand the patient as a whole person", and increased recognition of "problems of adjustment imposed by changing social and industrial conditions". Higher standards of

\footnotetext{
${ }^{67}$ See, for instance, 'Notes and News', The Almoner, 1953-4, 6 (1): p. 37, for an example of the continuous interest in the issue. "Last year a special enquiry disclosed that only 300 out of 1,300 hospitals which admit children, were up to that time allowing daily visiting by parents."
}

\footnotetext{
${ }^{68}$ Testimony from interview GCU/CCH T009 Almoners, GCU Archives.

${ }^{69}$ Testimony from interview GCU/CCH T008 Almoners, GCU Archives.

${ }^{70}$ Ibid.

${ }^{71}$ Testimony from interview GCU/CCH T013 Almoners, GCU Archives.
} 


\section{Scottish Medical Social Workers and Social Medicine, 1940-1975}

living, better general standards of education, "the provision for everyone of medical care, including such things as convalescence and surgical appliances, through the NHS, the use of National Assistance Departments to provide services for the sick and the extension of health education and medical after-care services by local health departments", had altered the almoners' work. Some medical advances had reduced their involvement, as in venereal diseases, but in others, such as skin treatments, demand increased. ${ }^{72}$ A similar sensitivity to change can be found in a later report by the renamed Social Work Department of the Glasgow Royal Infirmary: "Many of the patients' material needs are now met by the comprehensive provision of state legislation" but "problems of stress associated ... with the effects of a competitive standard of living, the faster pace of life and the high incidence of social breakdown" produced attempted suicides, unsupported mothers, and more patients with financial difficulties. Patients were "more aware of their emotional difficulties" and more able to "articulate them", and "the growing awareness of the medical and nursing staff of the inter-relation between illness and social conditions" meant social assessments were routinely requested. This was "an indication of our closer integration on the hospital team". 73

Clearly the social dimension was not static. Society changed as did the social sciences which were the knowledge base of the profession. Almoners in their journal and in their meetings displayed an acute interest in the changing practical and theoretical bases of their professional knowledge. Interviewees, even those who had been retired for many years, happily discussed the key works which had been the basis of their education and practice. From the first, the profession had had good contacts with university departments and an eye for new approaches. Jane Paterson, for instance had studied under Ethel Cohen and Harriett Bartlett at the Simmons College School of Social Work in Boston: "[T]hey had really thought out some of the important principles of social work and they were passed on to this country by all the people who went there." Such contacts were regular enough to become a joke: "One of our doctors used to make me laugh—she said that people ought to have put after their names BTA-I said 'What does that mean?'- she said 'Been To America',",74

Even those almoners with specific reservations had no doubts about the overall value of the education provided at the Institute. It was not just applicable social science but, involved "lectures from medical professors and people like that". More than fifty years later an interviewee was able to remember insights into specific diseases first picked up in such lectures. Many felt that they acquired an ability to discuss cases in doctors' terms and this meant that they were taken seriously. They also picked up aspects of medical culture, the absolute requirement for confidentiality for instance, which enabled doctors to talk freely and permit access to case notes. This was an important step to becoming part of the dramatis personae of the hospital: "Well, it gave me confidence, for one thing-confidence

\footnotetext{
${ }^{72}$ Institute of Almoners/Institute of Medical Social Workers papers from the British Association of Social Workers collection of the papers of the predecessor organizations 1890-1970, Modern Records Centre, University of Warwick, MSS.378 A15/16:20
}

\footnotetext{
${ }^{73}$ GRI, Department of Social Work, report to Board of Managers, 1972, Greater Glasgow Health Board Archive, HB 14.12/1-14.

${ }^{74}$ Testimony from interview GCU/CCH T016 Almoners, GCU Archives.
} 


\section{Chris Nottingham and Rona Dougall}

to link up with doctors and how to work with them." 75 At its best, this could result in a sense of belonging to a team:

Oh I think it was the medical staff and that, it was all one-you know, just one-oh it's stupid to say that, probably there were problems, but, I mean you knew why you were there, and the consultants were so different, they were just so much part of the whole-the whole kind of scene, you know. I mean, at that point they were registrars for quite a long time before they became consultants. But I mean, when they went for their interview for consultants, the whole department would say, "How did you get on?" you know the kind of thing. It was really, a very-there was no barrier. $^{76}$

\section{The High Point}

The late 1950s and early 1960s represented a high point for the profession. Almoners, or as they were increasingly calling themselves, medical social workers, were predominantly "comfortable middle-class" women with a degree and a professional qualification awarded by their own Institute. On the wards they wore a white coat. This was mentioned by most interviewees and was clearly of some importance. ${ }^{77}$ As a profession they had a comprehensive view of their practice. Several of those active in the period made reference to the work of Harriett Bartlett in the United States under whom Jane Paterson and other Scottish almoners had studied. In 1961 Bartlett published Social work practice in the health field, which described the position the profession had attained after fifty years of development. ${ }^{78}$ Bartlett, who was followed in all essentials by Zofia Butrym when she produced her own studies, provides the best insight into how medical social workers defined their purposes in this period. ${ }^{79}$ The key function for Bartlett was "clarifying and demonstrating to professional associates and others the psychosocial aspects of health, illness, and medical care and their meaning to patients and families". The social worker was able to make this contribution through "constant identification with the patient, and through being part of the health situation and viewing the problems from the patient's viewpoint". The medical social worker identified "the components of a psychosocial focus in social work terms and the manner of its development and integration" into the health field. She was familiar with the body of medical and public health knowledge, and translated "selected concepts into a social work frame of reference", and formulated "social work knowledge, values, insights and judgments in a form meaningful and useful for communication with the health professions". The social worker's function should also include the

\footnotetext{
${ }^{75}$ Testimony from interview GCU/CCH T014 Almoners, GCU Archives.

${ }^{76}$ Testimony from interview GCU/CCH T008 Almoners, GCU Archives.

${ }^{77}$ Distinguishing the almoner from other personnel was always an issue. From the 1910s at St Thomas's "hats, large at the time, were worn when going about the hospitals, or mixing with the patients, as a distinguishing mark." Marx, op. cit., note 46 above, p. 356.
}

\footnotetext{
${ }^{78}$ Harriett M Bartlett, Social work practice in the health field, New York, National Association of Social Workers, 1961. Bartlett had earlier written the equally influential work, Some aspects of social casework in a medical setting, New York, National Association of Social Workers, 1940 .

79 "The author who has contributed most in this respect is the American medical social worker, Harriett M Bartlett, and much of the following
} 
teaching of medical students and other health professionals. All activities were to be carried on "within a framework of multidiscipline practice" while "maintaining social work identity in the health setting". ${ }^{80}$ Bartlett preferred the term "social work in the health field" to "medical social work": "Social work is not engaged merely in supplementing the activities of other professions." 81

Job descriptions rarely translate exactly into day-to-day practice, yet it is easy to detect the influence of Bartlett's principles on Scottish practice. Practitioners had an accepted role in the education of other professionals and a view of their function which was fixed firmly between social and health fields. Their focus was on the patient and this involved not only seeking to improve outcomes for individuals but proposing changes to patterns of treatment.

Asked about almoners' influence on treatment, one interviewee mentioned heart patients: "[I]f we take the question of changing the coronary cases to activity rather than passivity, you know—get them out ... that was a direct thing." 82 Another, referring to the early 1960s, commented, "The social worker in my day was definitely seen as the person who picked up the psycho-social aspects of things." ${ }^{, 83}$ New areas, such as the care of leukaemia patients could prove particularly susceptible to influence. Plastic surgery was another:

I had responsibility for the burns and plastics unit at the Royal and we're talking about a time in the mid-60s when there was-and there still is-enormous social deprivation in the east-end of Glasgow and, you know, people were coming in with the most traumatic accidents in the burns unit, I mean, really, really bad, industrial accidents, and children who were burned which I got involved obviously, with the family situation there because of the-and of course in those days the rules in hospital were very strict, you know parents were allowed in for an hour in the afternoon and maybe half an hour in the evening and the trauma for children who'd been badly burned and being nursed in semi-isolation-so that was the very challenging stuff trying to help parents come to terms with guilt, because parents feel very guilty when their children have undergone some kind of accident, and to help people come to terms with the scarring and the healing - the long healing process that was involved in burns, I mean, when their whole body-image was completely altered and their emotional response was, was often to be become very withdrawn and depressed. ${ }^{84}$

Geriatrics and paediatrics were also areas where the input of almoners was welcome and considerable. In the latter they served as a channel for the dissemination of the ideas of John Bowlby and others on the importance of involving mothers in the care of children in hospital. They had a considerable impact on the approach to "unmarried mothers", where their commitment to focusing on the patient countered the tendency to treat them as pathological cases. ${ }^{85}$ The presence of a professional with a different disciplinary base was a critical factor in encouraging a questioning of existing wisdoms and

discussion reflects her influence." Zofia Butrym, Social work in medical care, London, Routledge and Kegan Paul, 1967, p. 3.

${ }^{80}$ Bartlett, Social work practice, op. cit., note 78 above, pp. 268-9.

${ }^{81}$ Ibid., p. 18.

${ }^{82}$ Testimony from interview GCU/CCH T014 Almoners, GCU Archives.

\footnotetext{
${ }^{83}$ Testimony from interview GCU/CCH T015 Almoners, GCU Archives.

${ }^{84}$ Ibid.

${ }^{85}$ For a more detailed account of almoners' impact in this area, see Rona Ferguson, 'Support not scorn: the theory and practice of maternity almoners in the $1960 \mathrm{~s}$ and 1970s', Oral History, 2003, 31 (2): 43-54.
} 


\section{Chris Nottingham and Rona Dougall}

challenging the "mechanistic approach". ${ }^{86}$ If we add their expertise in maintaining contacts with other parts of the health service and the social and voluntary sectors it is easy to see why their departments, as at the Glasgow Royal, were "seen as a very credible and integral part of that hospital scene". 87 One interviewee recalled:

Yes, yes, well we were regarded as a profession in our own right-doctors couldn't dictate to us what we did, although we took their advice, we always consulted them, you know, on what we were doing, but they couldn't dictate to us, that was recognized in those days. ${ }^{88}$

While most could recollect frustration in dealing with individual doctors, none criticized the profession as a whole. Many expressed personal gratitude to particular doctors who had helped them in their careers. All mentioned leading practitioners of social medicine as sources of inspiration. However, they were always unlikely to attract the same level of support from all doctors as social medicine has always been a difficult area for the medical profession, not least because, from the time of Chadwick to the present day, versions of the "social model of health" have been used to challenge medical pre-eminence. From a professional point of view the social approach is awkward for it involves a set of concerns that cannot be dealt with exclusively within the medical jurisdiction. Unlike, for example, complex surgery, where skill translates into effortless professional dominance, the practice of social medicine involves reliance on other professions and frequently draws the practitioner into politically controversial areas. Almoners seem to have had an almost instinctive understanding of this. One of the most frequent jibes levelled at them by the radicals in the social work profession in the 1960s was that they were "handmaidens of the doctors". That this caused offence is apparent from the frequency with which almoners mention it, but it was, at best, a gross simplification of a complex relationship. There was also sensitivity to the criticism that doctors contributed to their journal, but in retrospect their unease must seem a little misplaced. Professional machismo might require independence in all things but effective service delivery could only benefit from such cooperation. Almoners, as outlined in their response to the Cope Committee, saw themselves as an independent profession but recognized that if they were to work effectively they would have to do so as part a team of which the doctor would inevitably be leader. It is difficult to see how any other strategy could have proved effective. Even if it had been thought desirable, there was no opportunity to develop a separate jurisdiction, the basis of an ideal-type professional status. In practice, almoners worked towards a status of relative autonomy within the medical jurisdiction. They had confidence in the contribution they could make but realized this had to be achieved without compromising the position of other team members. One almoner in general practice argued that it could take up to two years to establish the relationship of trust with a doctor which was necessary for her to perform her duties most effectively. In time, she felt, the opportunity would arise when she could demonstrate her usefulness in a way that would persuade even the most intransigent doctor that she could be trusted to work on her own initiative. ${ }^{89}$

\footnotetext{
${ }^{86}$ Testimony from interview GCU/CCH T001 Almoners, GCU Archives.

${ }^{87}$ Testimony from interview GCU/CCH T015 Almoners, GCU Archives.
}

\footnotetext{
${ }^{88}$ Testimony from interview GCU/CCH T014 Almoners, GCU Archives.

${ }^{89}$ See Maureen Willis, 'Woodside Health Centre social work', Health Bulletin, 1973, 31 (3): 144-7.
} 


\section{Scottish Medical Social Workers and Social Medicine, 1940-1975}

How then, was the profession able to manage this delicate operation? Almoners could perform useful functions but, while this was the necessary foundation of success, it did not guarantee it. Opportunities existed but intelligent action was required to exploit them. A key asset was a cohesiveness based on a coherent and unifying view of purposes and strategy. This was possible because the natural advantages of smallness were underpinned by an effective system of professional education which involved mentoring. This was both an official element of the Institute's training and an informal practice which could continue for many years after qualification. It proved an effective way of transmitting the complexities of professional culture. Almoners in difficult situations, as in the Dundee example above, could always look to colleagues for support. All contacts made reference to almoners who had mentored and inspired them, and all in turn took on the role of mentor: "I found that most interesting, having students—-kept us in touch actually." 90 The endurance of the resulting networks was, and is, remarkable. Thirty-five years after the disappearance of their profession as a distinct organization, members stay in touch and many continue to be actively involved in the causes to which their professional lives were devoted.

This may have something to do with the fact that this was a predominantly, if not exclusively, female profession, although it might be difficult to say whether the co-operative practices rested on innate female qualities or were a result of the struggle to establish the profession. Our only male interviewee, at one time the sole male almoner in Scotland, was initially told, "men weren't eligible". In the 1940s, he recalled "there were four or five men in England" doing the job but not qualified and he suspected there were almoners "down in England, who were very anti-men coming into the profession". He felt, though, that his isolated state was probably because men "got better salaries as children's officers $\ldots$ and also as probation officers, so that they went into that field". 91

Although the profession undoubtedly served as an avenue for able women to secure rewarding work and positions of influence, career patterns reflected prevailing social expectations. Unlike other professions, there was no requirement for women to resign on marriage but some did accept that it meant the end of their career, and, of those who continued, most took a break of several years for children. Of the high number who did not marry, many took breaks or retired early to look after elderly parents. Gendered expectations may also go some way to explaining the unmistakably high quality of the candidates who entered the profession. An interviewee who qualified in the later 1940s commented:

So, at that stage, you were very limited in what you could do if you went to university; you were only allowed, you had to say what you would like to do, and, either teaching or social work or... that was really about it, that you were allowed to go ... otherwise ... or medicine obviously. But if you just said that you wanted to go in to further your education, I don't think it would have been on really. ${ }^{92}$

\footnotetext{
${ }^{90}$ Testimony from interview GCU/CCH T014 Almoners, GCU Archives.

${ }^{91}$ The same applied to Psychiatric Social Workers. "No, I can't remember any men PSWs - there may have been in England, certainly in Scotland I can't
}

remember any men PSW's. I think there were one or two in England." Testimony from interview GCU/CCH T014 Almoners, GCU Archives.

${ }^{92}$ Testimony from interview GCU/CCH T003 Almoners, GCU Archives. 


\section{Chris Nottingham and Rona Dougall}

An interviewee who trained in the late 1960s expressed a degree of awe for her senior colleagues:

They were women who probably were kind of middle-class backgrounds. I mean nowadays they'd be, you know, running businesses and becoming an MP and Prime Minister and things like that. They were extremely admirable women, you know, probably all been head girl and all that kind of stuff. $^{93}$

The fact that when the profession joined the generic social work profession in the 1970s a disproportionate number of members became directors of the new social work departments supports this insight.

Between 1940 and the late 1960s adept leadership and a committed membership had produced a profession in control of its own recruitment, education and regulation, and able to eliminate many aspects of work incompatible with professional status. The profession's expertise was not of the sort that could lead to any monopolistic position but almoners did establish a leading, if not exclusive, role in promoting a theoretical and practical understanding of the impact of social factors on illness and health care, and in creating and maintaining connections between health and social services. In the course of this, they contributed to the cohesion of health and social care systems, exercised influence over other health professions, helped to improve particular treatment regimes, as well as securing better outcomes for many individual patients. Their ability to achieve any of this rested on their capacity to establish and maintain at both representative and working levels a relationship of trust with doctors. They recognized that their ability to do the job they wanted to do rested on their capacity to work within the jurisdiction of the medical profession. As Roxburgh and McInnes had suggested in their argument to the Cope Committee, the almoners' advance required "a close and practical association with the medical profession". And it was precisely this which was to be called into question when the profession left the National Health Service and joined the new generic social work profession under the local authorities.

\section{The Merger and After}

Some medical social workers were sceptical about the merger from the first. Jane Paterson was never enthusiastic and later came to feel that the end of the training provided by the Institute represented the loss of the expertise which was her life's work. ${ }^{94}$ Even initial supporters expressed subsequent disappointment. Marjorie McInnes, the almoners' representative on the Cope Committee, and, as Senior Welfare Officer in the Scottish Office, deeply involved with the changes, recalled, "I had hoped that when MSWs with their pattern of team work at, quote, 'case level' were based in the local authority departments, this would have led to a steady increase in links to hospital, health centres and general practice, that their true experience would be reflected in policies of service provision." 95

\footnotetext{
${ }^{93}$ Testimony from interview GCU/CCH T010 Almoners, GCU Archives.

${ }^{94}$ Testimony from interview GCU/CCH T016 Almoners, GCU Archives.
}

\footnotetext{
95 'The medical social worker in Scotland', transcript of a witness seminar held in Library of Glasgow Caledonian University, 13 March 2004.
} 
Kay Carmichael, a prominent psychiatric social worker and adviser to the Kilbrandon Commission, which, as explained below, was one of the pillars of the generic profession in Scotland, was no less critical: "Now I was a fervent advocate of integration, as some of you will know, but I have to admit that for me I hoped that integration would mean that everybody would become psychiatric social workers-it hasn't happened."96

A full examination of these changes is beyond the scope of this current article but they have such important implications for what has gone before that it is difficult to ignore them. We shall content ourselves with raising two questions: why did the bulk of the profession accept the merger, and why did it prove detrimental to the cause of medical social work?

At this point it is necessary to discuss the Scottish dimension, for it was in the context of these changes that it assumed its greatest significance. As we have seen, Scottish almoners were never insular. Although they formed their own Scottish group within the Institute of Almoners, this was a matter of convenience. They obtained their specialist training at the Institute in London and they drew inspiration from the United States. Of those we spoke to, a substantial minority had considerable experience of working in England. Thus in all preeminent areas — organization, training and professional expertise-Scottish almoners were part of a British profession. They did, however, operate within the NHS in Scotland, which, as is now more widely understood, retained a number of distinguishing features. Jacqueline Jenkinson has shown that prior to the coming of the NHS there was a greater professional and public support for a state medical service. ${ }^{97}$ Marguerite Dupree has also identified a significantly higher degree of enthusiasm for the Health Service among Scottish doctors. ${ }^{98}$ John Stewart, in a comprehensive analysis of Scottish difference in the years from the formation of the NHS to the 1970s reorganization, argues hospitals were even more dominant than in England and that central government control was greater because of shorter lines of communication and the greater cohesiveness of professional and political elites. ${ }^{99}$ Stewart also supports the notion that the principle of a state service was better established, pointing out that the Scottish teaching hospitals were part of the NHS from 1948 onwards, unlike in England where they initially retained their independence. ${ }^{100}$

This distinctively Scottish approach to health and welfare questions can be traced back to the 1930s when the collapse of the regional economy convinced elite groups, irrespective of party affiliation, that the traditional frugal and laissez-faire approaches had become inappropriate. ${ }^{101}$ What came out of this was a collective outlook which has been variously described as "developmental", "corporatist", or "close knitted, interconnectedness". ${ }^{102}$ At the centre of the web was the Scottish Office, which encompassed health, welfare and educational services that in England were located in separate departments. Its position was also strengthened by the fact that Scottish local authorities were significantly weaker, and its ministers and officials were often prepared to mute partisan instincts in the cause of

\footnotetext{
${ }^{96}$ Ibid.

${ }^{97}$ Jacqueline Jenkinson, Scotland's health, 1919-1948, Bern, Peter Lang, 2002.

${ }^{98} \mathrm{M}$ Dupree, 'Towards a history of the NHS in Glasgow and the west of Scotland', in Chris Nottingham (ed.), The NHS in Scotland: the legacy of the past and the prospect of the future, Ashgate Press, Aldershot, 2000, pp. 138-49, on p. 140.
}

\footnotetext{
${ }^{99}$ John Stewart, 'The National Health Service in Scotland, 1947-1974: Scottish or British?', Historical Research, 2003, 76 (193): 389-410.

${ }^{100}$ Ibid., p. 389.

${ }^{101}$ Ian Levitt, Poverty and welfare in Scotland, 1890-1948, Edinburgh University Press, 1988.

${ }^{102}$ David McCrone, 'Towards a principled society: Scottish elites in the twentieth century',
} 


\section{Chris Nottingham and Rona Dougall}

furthering Scotland's interests within the UK system. As a result, welfare was given a high priority and professionals were more closely and comprehensively integrated into the system of government than elsewhere in the UK.

This particularly Scottish environment had undoubtedly assisted the medical social workers to establish their position, but in the 1960s it produced a model of change that was ultimately not favourable to their interests, but, none the less, difficult to resist. In Eileen Younghusband's view, Scotland managed the transition in social work much better, "It stole a march on England and Wales and achieved more revolutionary change with less turmoil." 103 The sources of the 1960s reforms in Scotland were the Morrison Committee of 1962, which recommended the transfer of probation services and officers to the social work sector, and the Kilbrandon Report of 1964, which argued for the transfer of youth justice out of the criminal justice system into social work. ${ }^{104}$ All these changes were incorporated in the White Paper Social work and the community, which proposed the setting up of generic social work departments with a strong community focus, and combining medical and psychiatric social workers with probation and children's officers in a unified profession. ${ }^{105}$ Moreover, in Scotland, the new local authority departments were firmly constructed "on the insights and skills of the profession of social work". 106 There was even the expectation that the directors of the new departments should themselves be qualified social workers. ${ }^{107}$ As if this were not enough to endear the reforms to the profession, the subsequent legislation, the Social Work (Scotland) Act 1968 included the famous Section 12, which stated that "[i]t shall be the duty of every local authority to promote social welfare", specifying that the new departments should advise other local government departments on the social implications of their policies. ${ }^{108}$ In this atmosphere it is easy to see why the medical social workers in Scotland expressed fewer misgivings about their incorporation into the new profession, and their withdrawal from the hospital and the NHS, than their counterparts in England and Wales. ${ }^{109}$

It is also important to take account of the broader political climate. For anyone who believed that the social sciences had a capacity to contribute to human well-being the later 1960s represented a period of high expectation. Social problems of all sorts were widely aired but the prevailing assumption was that the social disciplines contained the seeds of applicable solutions. Moreover, the public sector was expanding and seen as a source of solutions rather than a sink of problems. The embryonic social work

in Tony Dickson and James H Treble (eds), People and society in Scotland. Volume 3, 1914-1990, Edinburgh, John Donald, 1994, pp. 176-200, p. 198; Stewart, op. cit., note 99 above, p. 400; R J Findlay, 'Scotland in the twentieth century: in defence of oligarchy?', Scottish Historical Review, 1994, 73: 103-12, p. 110.

${ }^{103}$ Eileen Younghusband, Social work in Britain 1950-1975: a follow-up study, London, George Allen and Unwin, 1978, vol.1, p. 250.

${ }^{104}$ Report of the Departmental Committee on the Probation Service, Cmd 1650, Edinburgh, HMSO, 1962; Report of the Committee on Children and Young Persons, Scotland, Cmd 2306, Edinburgh, HMSO, 1964.

\footnotetext{
${ }^{105}$ Social work and the community, Cmd 3065, Edinburgh, HMSO, 1966.

${ }^{106}$ Younghusband, op. cit., note 103 above, p. 251.

${ }^{107}$ Ibid., p. 252; and Social work and the community, op. cit., note 105 above. By the time of the creation of the big regional social work departments after local government reorganization in 1975 nine of the twelve directors of social work were actually qualified social workers.

${ }^{108}$ Younghusband, op. cit., note 103 above, p. 252.

${ }^{109}$ Derek T Carter, 'Attitudes of medical social workers towards reorganization', Br. J. Social Wk, 1971, 1 (3): 255-76.
} 


\section{Scottish Medical Social Workers and Social Medicine, 1940-1975}

profession, untarnished by the cases that were to damage its authority, contributed to and drew sustenance from this mood. ${ }^{110}$ A decision to exempt oneself from the changes, particularly as they appeared in Scotland, would have appeared a retrograde step. David Colvin, who viewed the changes from a position of leadership within the Scottish Office, recalled, "[T]he pressure for integration was incredible." At a meeting of the newly formed British Association of Social Workers, attended by 280 people, only two voted against integration. ${ }^{111}$ For Joan Baraclough, Secretary of the newly formed British Association of Social Workers, the title of "medical social worker" was anachronistic: "a. it was an outdated title, b. it gave a wrong impression of the nature and function and, c. ... it left people in this country out of kilter with the international world."112 Moreover, medical social workers had always been progressively minded and perpetually selfquestioning. The pages of Medical Social Work in the critical period reveal impatience with what had been achieved and a questioning of existing practices. ${ }^{113}$

There was also the prospect of immediate benefits. For one medical social worker who worked with "unmarried mothers" the change brought an immediate upgrading and new statutory powers, "We very quickly moved into doing our own adoptions. When I say that, I mean, you know, presenting our adoption to the adoption panel, and doing the assessment, and being involved in the, the picking of the parents." 114 Moreover, it was not unreasonable to anticipate that medical social workers might assume a leading role in moulding a new profession high on ambition but low on expertise. It is easy to see why the reservations of individuals never developed into a bloc of opposition.

In the event, the new generic profession, both in Scotland and elsewhere, developed an ethos which was unsympathetic to the traditions and practices of medical social work. ${ }^{115}$ The fact that youth justice became such a focus of debate did not help, nor did the iconoclastic style of many within the new profession. For a good number of practitioners

\footnotetext{
${ }^{110}$ One view had it that social work which had been "constructed on an enormous landmass of consensus ... suddenly in 1980 it appeared to be perched on a tidal sandbank", Bill Jordan and Nigel Parton,

'Introduction', in Bill Jordan and Nigel Parton (eds),

The political dimensions of social work, Oxford, Basil

Blackwell, 1983, pp. 6-7.

111 'The medical social worker in Scotland', transcript of a witness seminar held in Library of Glasgow Caledonian University, 13 March 2004.

${ }^{112}$ Ibid.

${ }^{113}$ See, for example, McDougall, 'Whither medical social work?', Medical Social Work, 1970, 22 (10): 24-5: "the social worker in the local authority can develop a professional relationship to clients appropriate to the circumstances which is far more meaningful to the client than the pseudo-freedom in the secondary setting of the hospital where the very nature of the hierarchical structure detracts from the professional freedom of non-medical staff." A study for the Institute (Majorie Moon, The first two years, London, Swale Press for the Institute of Medical Social Workers, 1965) had interviewed newly qualified MSWs in their first years of practice and concluded that
}

the training had failed to equip them for the difficulties of working with medical staff. Zofia Butrym produced a critical study of the work of the large MSW department in the Hammersmith Hospital in 1968. Individuals had excessive case loads, spent too much time on administration, and could not find enough time for discussions with medical and nursing staff. The lack of understanding of the social work role on the part of the clinical staff resulted in a poor use of the referral system and a good deal of unmet need. Zofia Butrym, Medical social work in action, Occasional Papers on Social Administration, No. 26, London, G Bell, 1968, pp. 57-68. Helen Bate caught this mood and illustrated the vulnerability of the medical social workers to the appeals of a different kind of social work. "Is it too much to ask that we should sometimes have something to say on a larger and more constructive scale?" Helen A Bate, 'The basic task of social work in hospital today', Medical Social Work, 1970, 22 (10): 352-5.

${ }^{114}$ Testimony from interview GCU/CCH T001 Almoners, GCU Archives.

${ }^{115}$ Many difficulties were caused by high expectations not being matched by enough trained workers: "At the time of the setting up of the social 


\section{Chris Nottingham and Rona Dougall}

this involved a questioning, if not an outright rejection, of the social worker's traditional role and methodology. The radicals rejected a focus on individuals in favour of a challenge to prevailing social values and structures. Purposes were defined in ways which seemed more political than professional. Our interviewees were sensitive to, though not dismissive of, this change of emphasis:

And the whole kind of difference in the approach was summed up by this wonderful thing about, you know, the woman going in to see her social worker who says, "How do you feel about your rats today Mrs Smith?" And (laughs) it was that kind of social work, or that kind of perceived social work that people in the 1970 s were wanting to get away from. ${ }^{116}$

As Peter Leonard put it in Medical Social Work, "It is suggested, for example, that casework is irrelevant to many people's problems and that what is needed is structural and economic change, rather than attempts to help the individual adapt to his underprivileged position in society." 117 Casework, which had played an important role in the development of social work professionalism, came under attack. In practice it was a very broad category encompassing different approaches. ${ }^{118}$ At this time, however, it was often represented as a rejection of social approaches in favour of psychiatric and individualistic ones. ${ }^{119}$ The older methods were associated with "elitism", which, of course, was a self-evident evil. Fred Edwards, first head of the Strathclyde Social Work Department, regarded his former medical social workers as an "invaluable source" of expertise but recognized that they did not fit easily into "the kind of rather industrialised pattern of social work that one saw in the West of Scotland ... looking to trade unions rather than to professional associations". ${ }^{120}$

Yet, while medical social workers could cope with, and in some cases actually join in, many aspects of the criticism of previous practice, there was an underlying hostility to the medical profession that posed greater difficulties, for it represented a challenge to the core theoretical and practical principles on which the profession had developed. ${ }^{121}$

work department we had only about a thousand professionally trained social workers-sorry a thousand trained social workers in the whole of Scotland. And by training- that included people that just now would not be thought of as half trained in current standards. So we were very thin on the ground", David Colvin, 'The medical social worker in Scotland', transcript of a witness seminar held in Library of Glasgow Caledonian University, 13 March 2004. According to the Social Work Services Group there were in 1968, 959 local authority social workers of whom 292 held a professional qualification. This included Probation Officers but not, of course, medical and psychiatric social workers. By 1974 the total was 2,185, of whom 1,122 were trained. Younghusband, op. cit., note 103 above, p. 252. As a comparison, in 2004 there were 7,000 fully trained social workers in Scotland, British Association of Social Workers, press release, 30 June 2004.

${ }^{116}$ Testimony from interview GCU/CCH T010 Almoners, GCU Archives.
${ }^{117}$ Peter Leonard, 'Social change and the social work profession', Medical Social Work, 1968, 21 (3): 64-9, p. 68.

${ }^{118}$ It is important to remember that casework had always had its opponents. See, for example, Barbara Wootton, Social science and social pathology, London, George Allen and Unwin, 1959, pp. 276-81.

${ }^{119}$ See, for instance, Ray Lees, 'Social work, 1925-50: the case for a reappraisal', Br. J. Social Wk, 1971, 1 (4): 371-9, who argued that accounts of past practice were frequently over simplified. For a history of what social casework meant in the context of professional developments in the USA, see Roy Lubove, The professional altruist, Cambridge, MA, Harvard University Press, 1965, pp. 113-17.

120 'The medical social worker in Scotland', transcript of a witness seminar held in Library of Glasgow Caledonian University, 13 March 2004.

${ }^{121}$ The depth of the hostility of the radical social worker towards the medical profession and those who 
As many interviewees recalled, they were referred to as "handmaidens of the doctor". One observed, "the people that made that remark were the social workers in the area teams." ${ }^{22}$ Kay Carmichael, a prominent radical, said, "[W]e showed a distressing lack of respect for doctors." 123 One former medical social worker commented on her new social work colleagues: "[T]hey had to come to case conferences whenever possible, and, I must say, I wasn't always enchanted with the area teams, at their behaviour, but never mind, at the beginning particularly. Some of them had real hang-ups with the doctors." Antipathies were mutual. She recalled one doctor's comment: "I expected better from you ... I mean you're one of us, not like those social workers out there."124

In their generic training, social workers were now more likely to encounter books that set the "social model" of health on a collision course with the "medical model", when the whole practice of medical social work rested on seeing the two as complementary. ${ }^{125}$ In the mind-set of the radical sociologist or social worker a proper respect for the social model seemed to require a rejection of the medical, which was often presented as self-aggrandisement by doctors. Butrym made the point very clearly: "The view we [medical social workers] took on this is certainly incompatible however with a perception of social work contribution to health care in isolation from or in opposition to medicine[,] as we would consider this to be a denial of the bio-psychosocial unity in health and in illness." ${ }^{126}$ The development of the generic social work profession found medical social workers caught between two sparring jurisdictions.

The consequences were clear in the testimony of one interviewee. She believed in a measure of professional specialization. A social worker could never be effective "if you're trying to sort out psycho-social problems and you don't have a clue what the clinical scene is". Yet her own approach was innovative; she had chosen to leave the hospital and had set up a student teaching unit in one of the Glasgow peripheral housing schemes. She accepted that this isolated her from former colleagues in hospitals, "Well obviously I wasn't part of their set up any more", but new colleagues were less than welcoming: "There was a sort of feeling that almoners were very middle class, and well-educated women who were quite

were prepared to work with it, is sometimes difficult to appreciate. See Paul Bywaters, 'Social work and the medical profession - arguments against unconditional collaboration', Br. J. Social Wk, 1986, 16 (6): 661-77. In addition to recounting the familiar complaints - that MSWs could be seen as doctors' handmaidens and that doctors contributed articles to medical social workers' journals-Bywaters argued that "few social workers have taken the position that social work may have a contribution to make to health quite independent of the medical profession, or that social workers may need to work actively to oppose current forms of service or to join with others to roll back the domination of medicine and its commercial and professional allies" (p. 675). Butrym replied, taking the author to task for his failure to appreciate that medical social workers had asserted "social work values in their practice in both hospitals and other settings". Zofia Butrym, Letter to the Editor, Br. J. Social Wk, 1987, 17 (3): 305-6, on p. 305.
${ }^{122}$ Testimony from interview GCU/CCH T001 Almoners, GCU Archives.

123 'The medical social worker in Scotland', transcript of a witness seminar held in Library of Glasgow Caledonian University, 13 March 2004.

${ }^{124}$ Testimony from interview GCU/CCH T001 Almoners, GCU Archives.

${ }^{125}$ See, for example, Nicky Hart, The sociology of health and medicine, Ormskirk, Causeway, 1985, a widely used text which retailed the new conventional wisdom. "In present day Britain, it is difficult for most people to separate their ideas about health from their ideas about medicine. This is because the medical profession has successfully persuaded us that our personal health depends upon high standards of medical care." "Medicine has not made a significant contribution to improving people's health in the past and much of the treatment carried out in the NHS today has never been carefully evaluated" (pp. 7-8).

${ }^{126}$ Butrym, op. cit., note 121 above, pp. 305-6. 


\section{Chris Nottingham and Rona Dougall}

precious in the way they operated." The department she worked for seemed deeply bureaucratic:

After Social Work Scotland area teams became the kind of powerhouse of social work, so area teams were the kind of nuts and bolts of the big powerful emerging social work departments. Power became quite an important thing for social workers that emerged in the $70 \mathrm{~s} .{ }^{127}$

One medical social worker felt she could still be effective but that she was relying on contacts already established: "It might have been difficult if I had gone somewhere else where nobody knew me who would just think 'That's somebody from the welfare department phoning up'." 128 For another working in the community, "it was building up the kind of relationship within the hospital that was so valuable", but it was precisely this which was constantly called into question. ${ }^{129}$ One interviewee systematically investigated the attitudes of doctors working with social workers in health centres: "Their response was that they wanted ... people that they knew to be part of their team and they didn't want to be just given any old social worker to work with their patients or their team." If the social work department was unsympathetic "they'd just say 'Och! We'll do without, get the nurses to do it" ". ${ }^{130}$ But in her view, it was by developing a relationship with doctors that she was able to resist them more effectively. If a doctor wished prematurely to discharge a patient:

I would say "Wait a cotton-picking minute, I've not done an assessment on this patient and I don't know anything about them and that'll take me a week, so I'll come back and see." You know, and with a bit of humour as well, but you know I think, and that's not the style of primary social workers in a primary team, they're always fighting, at loggerheads, I mean I fought too, I was confrontational when it was appropriate to be confrontational, but the minute I saw a doctor my hackles didn't rise. ${ }^{131}$

It is important to stress that medical social workers continued to do useful work and develop their practice. One interviewee mentioned work with non-accidental injuries in children where knowledge of medical issues and ability to work with doctors produced important changes. ${ }^{132}$ Another, concerned with reproductive issues, spoke of how her experience enabled her to stand up to doctors:

But I had to let him know where I was coming from. I wasn't, you know, I wasn't somebody who had been schooled in doing excellent work with the housing department or social security, I had an expertise about dealing with reproductive issues.... they're gynaecologists, and gynaecologists are surgeons, and we know as medical social workers how surgeons approach life, you know. I mean, my God! we'd need them if we had problems, but they're not the answer to everything. ${ }^{133}$

Another developed pioneering and imaginative practice in children's cancers:

I was there when the doctor told them the diagnosis, I was there, picked up the pieces, and worked with them from then on, through their journey through this child's treatment to survival or not, and

\footnotetext{
${ }^{127}$ Testimony from interview GCU/CCH T015 Almoners, GCU Archives.

${ }^{128}$ Testimony from interview GCU/CCH T013 Almoners, GCU Archives.

${ }^{129}$ Testimony from interview GCU/CCH T001 Almoners, GCU Archives.
}

\footnotetext{
${ }^{130}$ Testimony from interview GCU/CCH T015 Almoners, GCU Archives.

${ }^{131}$ Ibid.

${ }^{132}$ Testimony from interview GCU/CCH T001 Almoners, GCU Archives.

${ }^{133}$ Testimony from interview GCU/CCH T010 Almoners, GCU Archives.
} 
the phases of that are amazing ... my role was always with the nursing staff and the others was to support- to let them feel they could cope ... it was very difficult for parents to get angry with people that are in control of treatment and eh, so it was OK to say things to me, negative things about members of staff, negative things about the way they were feeling, that was OK, because I wasn't part of the child's treatment, I was detached from that. ${ }^{134}$

Even the most effective of the former medical social workers felt they were the last of a line: "maybe there aren't many social workers left like me". ${ }^{135}$ Another commented, "I mean there are local authority social workers, I think attached to various hospitals, but nobody does the job that they did." ${ }^{136}$ Yet another, returning to hospital as a patient, noted how social work had become almost invisible, "the social worker's office was tucked away in the basement, down in the X-ray department, which seemed a long corridor, you know, to walk all that distance, whereas when I was a medical social worker, we had our offices near the entrance, always-easy access."137

Our interviewees rarely criticized their new colleagues. One, not untypical, recorded her admiration for a new untrained colleague, "[S]he was very, very good and she had a tremendous relationship with the people that she dealt with and also you found that these people did an awful lot with young people outwith their work, you know in the evenings." She acknowledged their expertise:

They were very good at their jobs-just though their years of experience ... there was a man in Glasgow I remember and he had no training because he was sent for training afterwards, but I had to do a joint visit with him ... he talked to the person - I think he was an old drunk or somethingin the language this person could understand and he got respect, whereas I would've just been laughed at. ${ }^{138}$

However, they recognized that social workers lacked the particular skills necessary to engage effectively with the medical profession: "If you went to an area team and interviewed social workers about the kind of things you're asking me about, they wouldn't be able to talk to you about it because they don't have any tradition in that-completely different animal." ${ }^{139}$ A 1972 report from the Almoners' Department of the Glasgow Royal suggests that even before the final move into the local authority, one of the links that had taken so long to build up was breaking down: "Since the effect of the MSW service depends so largely on the cooperation and understanding of the medical staff, it is regretted that medical students have no opportunity of gaining some knowledge of the MSW function." "Systematic lectures on the social implications of illness no longer form part of the medical students' curriculum." 140

It was not illogical for medical social workers to throw in their lot with the new generic profession of social work and, in the circumstances, it is difficult to see how any other decision could have been taken. Yet, as things worked out, it meant the exchange of a

\footnotetext{
${ }^{134}$ Testimony from interview GCU/CCH T015 Almoners, GCU Archives.

${ }^{135}$ Ibid.

${ }^{136}$ Testimony from interview GCU/CCH T016 Almoners, GCU Archives.

${ }^{137}$ Testimony from interview GCU/CCH T014 Almoners, GCU Archives.
}

\footnotetext{
${ }^{138}$ Testimony from interview GCU/CCH T012 Almoners, GCU Archives.

${ }^{139}$ Testimony from interview GCU/CCH T015 Almoners, GCU Archives.

${ }^{140}$ GRI, Department of Social Work, report to Board of Managers, 1972, Greater Glasgow Health Board Archive, HB 14.12/1-14.
} 
subordinate, but not subservient, position within the medical jurisdiction for an uncertain future in a professional jurisdiction which was combative, muddled and short of the resources necessary to deliver on its promises. The new profession was, moreover, broadly unsympathetic to their skills and outlook. In the process, social workers in the health field lost their sense of common purpose and their capacity to advance the cause of social medicine. The consequences were unfortunate for medical social work itself, but even more so for the Health Service and its patients, for what was lost was a body of practitioners who could have continued to inhabit those difficult zones between the social and the medical outlooks, the hospital and the community, and the patient and the medical professional. From that position they might have done much to monitor and alleviate some of the Service's enduring weaknesses. 